Omni-Akuatika, 13 (1): 66-77, 2017
ISSN: 1858-3873 print / 2476-9347 online
Research Article

\title{
The Quality of Water of the Downstream of the Siak River, Riau Province, Based on Tidal Condition
}

\author{
Yuliati ${ }^{\left.1,2^{*}\right)}$, Etty Riani ${ }^{3)}$, Bambang Pramudya N. ${ }^{4)}$, Achmad Fahrudin ${ }^{3)}$ \\ 1) Doctoral Program of Enviromental Resource Management, Post Graduate School, Bogor Agricultural University \\ 2) Department of Aquatic Resource Management, Faculty of Fisheries and Marine Sciences, Riau University \\ 3) Department of Aquatic Resource Management, Faculty of Fisheries and Marine Sciences, Bogor Agricultural \\ University \\ 4) Department of Mechanical Engineering and Biosystem, Faculty of Agricultural Engineering and Technology, Bogor \\ Agricultural University \\ *)Corresponding author: yuliatioryza@yahoo.co.id
}

Received 12 January 2017; Accepted 27 March 2017; Available online 31 May 2017

\begin{abstract}
The quality of water in a river is affected by its natural condition and pollutant input originated from activities conducted around the river. In the Siak river, however, the black water effect influences the distribution of the pollutant in general. To understand the quality of water in the black water affected by an area, a study was conducted from December 2015 to July 2016 . The water was sampled during low and high tides, in 8 sampling sites that were distributed along the river, from the mouth of the river in Siak Sri Indrapura Regency to upstream in Palas Village, Kampar Regency (around $180 \mathrm{~km}$ from the mouth of the river). The results showed that in the downstream of the Siak river, the quality of water during the low and high tides was worse than the $3^{\text {rd }}$ Class Water Quality Standard issued by the Government Regulation (GR No. 82 / 2001) except for the concentration of nitrate, total coliform, Hg, oil and fat. The BOD was 14-39.2 mg/L (the high tide) and 17-45.6 mg/L (the low tide), COD was 51.76-80.62 mg/L (the high tide) and 51.76-69.12 mg/L (the low tide), $\mathrm{NH}_{3}-\mathrm{N}$ was $0.03-1.09 \mathrm{mg} / \mathrm{L}$ (the high tide) and 0.03-0.92 $\mathrm{mg} / \mathrm{L}$ (the low tide), while the $\mathrm{NO}_{2}-\mathrm{N}$ was $0.13-0.17 \mathrm{mg} / \mathrm{L}$ (the high tide) and 0.13-0.22 $\mathrm{mg} / \mathrm{L}$ (the low tide). Based on the Storet Index, the water of the downstream in the Siak river during the low and the high tide can be categorized as heavily polluted (score -52 to -70 ), and it tends to decline during the high tide.
\end{abstract}

Keywords: The quality of water, the siak river, storet index, tide

\section{Introduction}

Rivers have versatile functions for human life and livelihood. Currently the condition of almost $80 \%$ of the river water in Indonesia shows a decline (MOE, 2013). The decline of the quality of river water has been characterized by increasing the parameters of Biological Oxygen Demand (BOD) (Lee and Nikraz, 2015), total ammonium, nitrite, phosphate (Dimitrovska et al., 2012; Kaur and Dua, 2016), Chemical Oxygen Demand (COD) (Ahmed et al., 2015) and the level of heavy metals (Suthar et al., 2009; Azizullah et al., 2011; Bhuiyan et al., 2013).

The Siak River is one of the main rivers in Indonesia, but its water quality has been declining. This River is one of the four main big rivers in Riau Province, and it is the deepest river in Indonesia (DCCOES, 2015). The upstream of Siak River watershed consists of two headstreams, Tapung Kiri River and Tapung Kanan River, which unify in Palas region, at Kampar Regency in the Siak Besar River, while the downstream is the Siak Besar River in Palas Village, in Kampar Regency up to Siak estuary in Siak Sri Indrapura Regency (DOPW, 2005). Besides, the Siak river has characteristic as a black water river (Baum et al., 2007; Wit et al., 2016), its water is reddish brown (Rixen et al., 2008; Siegel et al., 2009), as it contains humic acid compound (Amri, 2007; Siegel et al., 2009) that comes from the leaching of the surrounding 
peat soils (Rixen et al., 2008). Moreover, the Siak River also has other unique features, such as the high levels of dissolved organic carbon, the low dissolved oxygen levels, and under the influence of tides (Baum et al., 2007; Rixen et al., 2008; Rixen et al., 2010; Baum and Rixen, 2014; Husnah et al., 2014; Putri and Pholmann, 2014).

The Siak River is a national strategic river and serves as navigation, transportation, fishing, a source of raw water for industries and PDAM Tirta Siak in Pekanbaru. Then, it also serves as a daily source of water for most people who live along the river's flow (RBA III Sumatera, 2015). The Siak downstream watershed is a critical watershed since the quality and the quantity of the water is decreasing due to the influx of domestic and industrial waste (DCCOES, 2015), as well as the waste from oil palm plantation (Baum and Rixen, 2014). The decline of the Siak River quality adversely affects the communities around the river, for example, there are complaints of skin diseases (Ismy et al., 2012) and a decrease in fish population (Iskandar and Dahiyat, 2012).

Concerning about the condition of the Siak River, it is necessary to control the river pollution through the analysis of the quality of water based on the tides. The quality of water when the tides come can give an information in making a decision to control the pollutant in the Siak River. It is caused by the characteristics of the Siak River which are influenced by the tides, it reaches $\pm 200 \mathrm{~km}$ to the upstream of the river (Siegel et al., 2009; Putri and Pohlmann, 2014). In general, the condition of the tides affects the pollutant distribution in the Siak River as reported by Siegel et al., (2009), the pattern of waste distribution in the Siak River is affected by the tides and the high tides that reduce the conveyance capacity of the Siak River (Nurhamidah et al., 2016). According to Chihhao et al., (2009) stated that the tide patterns in the river influence the pollutant movement in the stream because of the flow fluctuation. Otherwise, the tides also cause the pollutant hardly waste to oceans (Toriman et al., 2011) which finally influences the quality of water in the river (Gasim et al., 2015; Rim-Rukeh, 2016). The poor quality of water causes the water of the river unreasonable to be used and needs efforts in management and recovery.

Although many researches have been carried out to know the water quality of the Siak River (Amri, 2007; Husnah et al., 2014; Rixen et al., 2008; Rixen et al., 2010 ; Baum and Rixen, 2014), the study on the water quality at the tides of the Siak River has been rarely reported. Some studies on the tides of the Siak River including Nedi (1999), reported about the water quality of the Siak River from the Palas village to the Buatan village. Siegel et al., (2009) reported about the tidal effects on the characteristics of chlorophyll, particle, and carbon dissolved in Siak estuary. In addition, Putri and Pohlman (2014) also reported about the particle hydrodynamic model in the Siak estuary. For serving Siak River as the Policy of Governor number 12 in 2013, it is important to do a research on some physical and chemical parameters of the quality of the Siak River on tides. Hence, the quality of downstream water of the River Siak in Riau Province becomes necessary to be studied based on tidal condition.

\section{Materials and Methods}

\section{Time and place}

This research was conducted in the Siak River in Riau Province (Figure.1). It was conducted in December 2015 until July 2016. And, it was located at the following coordinates: 010 14' 06.14" north latitude- 1020 10.01' 11" East Longitude up to $0033^{\prime}$ 04.7" North Latitude 101 24' 00.8" East Longitude. Eight sampling stations were established that was started from the mouth of the river up to $180 \mathrm{~km}$ upstream in Palas village, Pekanbaru City.

\section{Sampling methods and analytical procedures}

Sampling was carried out at the high and the low tides based on the tidal predictions (Pelindo 2015 - 2016). It was using Van dorn water sampler in the middle and both sides of the river banks which was subsequently composited. Samples were put into polyethylene bottles and added $\mathrm{H} 2 \mathrm{SO} 4$ up to $\mathrm{pH}<2$, for the analysis of ammonia, nitrite and nitrate. To analyze the total coliform, the sample was placed into glasses bottles. Meanwhile to analyze total phosphate, and BOD, water samples were stored in the ice box containing ice at a temperature of $40 \mathrm{C}$. The samples that intended for heavy metal analysis were filtered with $0.45 \mu \mathrm{m}$ filter paper and were given preservative $\mathrm{HNO} 3$ to $\mathrm{pH}<2$ (APHA, 2012). The measurement of nitrate, nitrite, ammonia and phosphate used spectrophotometer thermo spectronic 20D+. $\mathrm{Pb}$ and $\mathrm{Cd}$ metal that were measured by using Flame Atomic Absorption Spectrophotometer. Besides, $\mathrm{Hg}$ metal was measured by using Hidrid Atomic Absorption Spectrophotometer (Perkin Elmer, Pin 
AAcle 900H). Furthermore, samples were analyzed in triplicate to provide representative mean values. Duplicate method blanks were also processed and analyzed alongside the samples to check any loss or cross contamination. As a result, the differences of the concentrations between the determined and certified values were less than $2 \%$. To validate the analytical methodology, recovery studies were performed that percentages were $101 \%$ for $\mathrm{Pb}, 103 \%$ for $\mathrm{Cd}$ and 102 for $\mathrm{Hg}$. In addition, accuracy was determined by using Material Reference Certified Analysis (CRM).

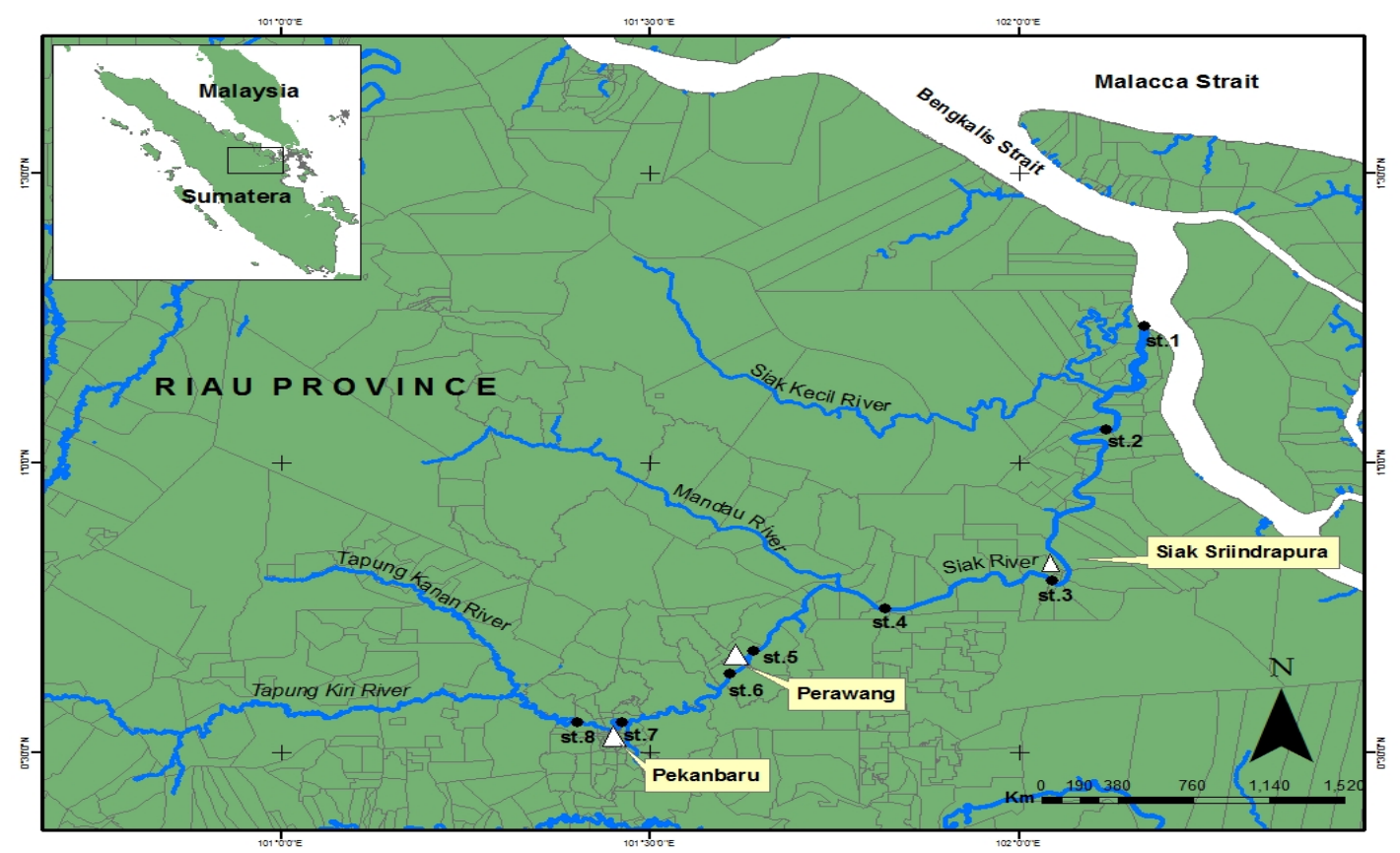

Figure1. The Map of research location

Table1. The Physical, chemical and aquatic biological parameters along with the methods used

\begin{tabular}{|c|c|c|c|c|c|}
\hline No. & Parameter & Unit & Test Method & Method & Analysis \\
\hline $\begin{array}{l}1 . \\
2 . \\
3 .\end{array}$ & $\begin{array}{l}\text { Temperature } \\
\text { TSS } \\
\text { Salinity }\end{array}$ & $\begin{array}{c}{ }^{0} \mathrm{C} \\
\mathrm{mg} / \mathrm{L} \\
\%\end{array}$ & $\begin{array}{l}\text { SNI 06-6989.23-2005 } \\
\text { SNI 06-6989.27-2005 }\end{array}$ & $\begin{array}{l}\text { Thermometer } \\
\text { Gravimetry } \\
\text { Hand } \\
\text { Rephractometer }\end{array}$ & $\begin{array}{l}\text { In situ } \\
\text { Laboratory } \\
\text { Laboratory }\end{array}$ \\
\hline $\begin{array}{l}5 . \\
6 . \\
7 . \\
8 . \\
9 . \\
10 .\end{array}$ & $\begin{array}{l}\mathrm{DO} \\
\mathrm{BOD} \\
\mathrm{COD} \\
\mathrm{NO}_{3}-\mathrm{N} \\
\mathrm{NO}_{2}-\mathrm{N} \\
\mathrm{NH}_{3}-\mathrm{N}\end{array}$ & $\begin{array}{l}\mathrm{mg} / \mathrm{L} \\
\mathrm{mg} / \mathrm{L} \\
\mathrm{mg} / \mathrm{L} \\
\mathrm{mg} / \mathrm{L} \\
\mathrm{mg} / \mathrm{L}\end{array}$ & $\begin{array}{l}\text { SNI 06-6989.14-2004 } \\
\text { APHA, 2012, 5210 } \\
\text { APHA, 2012, 5220-D } \\
\text { APHA, 2012, 4500- } \mathrm{NO}_{3}-\mathrm{N} \\
\text { APHA, 2012, 4500- } \mathrm{NO}_{2}-\mathrm{N}\end{array}$ & $\begin{array}{l}\text { DO Meter } \\
\text { Winkler Titration } \\
\mathrm{K}_{2} \mathrm{Cr}_{2} \mathrm{O}_{7} \text { Reflux } \\
\text { Spectrophotometer } \\
\text { Spectrophotometer }\end{array}$ & $\begin{array}{l}\text { In situ } \\
\text { Laboratory } \\
\text { Laboratory } \\
\text { Laboratory } \\
\text { Laboratory } \\
\text { Laboratory }\end{array}$ \\
\hline 11. & Total & $\mathrm{mg} / \mathrm{L}$ & $\begin{array}{l}\text { APHA, } 2012,4500-\mathrm{NH}_{3}-\mathrm{N} \\
\text { APHA, 2012, 4500-P }\end{array}$ & Spectrophotometer & Laboratory \\
\hline 12. & Oil and Fat & $\mathrm{mg} / \mathrm{L}$ & APHA, 5520-B & Gravimetry & Laboratory \\
\hline 13. & Total Coliform & MPN/100 & АРНА, 2012, 9222 & MPN Method & Laboratory \\
\hline 14. & $\begin{array}{l}\mathrm{Pb}, \mathrm{Cd} \text { and } \\
\mathrm{Hg}\end{array}$ & mg/L & $\begin{array}{l}\text { APHA, 2012, 3111-B, } \\
3030-B\end{array}$ & AAS & Laboratory \\
\hline
\end{tabular}


Data analysis

The data of water quality in the Siak River when the tides happened was analyzed descriptively referring to a Government Rule (GR) number 82 in 2001 Class III about the standard of water quality served to cultivate fish in fresh water, animal husbandry, to irrigate gardens and others which require the standard of water quality. It is based on the policy of Riau governor Number 12 in 2003 about the allocations and the water quality standard of the Siak River in Riau Province, which is decided that the second inter node of Siak River (from Palas to the estuary in Apit River Village) is the third class of the water quality standard.

The data analysis of the water quality in the Siak River downstream was also conducted through STORET Index approach (MOE, 2003). The STORET index has been used to determine the status of Water surface in Indonesia (Ratnaningsih, 2010). The STORET index needs a large number of water quality parameters (Tallar and Jiang-Ping, 2015). In this research, the parameters used to calculate the storet index are temperature, $\mathrm{pH}, \mathrm{DO}, \mathrm{BOD}_{5}, \mathrm{COD}$, Nitrit $\left(\mathrm{NO}_{2}-\mathrm{N}\right)$, Nitrat $\left(\mathrm{NO}_{3}-\mathrm{N}\right)$, ammonia $\left(\mathrm{NH}_{3}-\mathrm{N}\right)$, total posfat, total coliform, oil, fat and heavy metal $\mathrm{Pb}$, and $\mathrm{Cd}$.

\section{STORET Index}

The STORET method is a method to determine the water quality status, to determine the parameters that have met or exceeded the water quality standard (MOE, 2003). This method is always used by government agencies and nongovernment agencies (Sholichin et al., 2010). Determining the status of water quality by using index storet have a plus; there is a flexibility of the number and the types of water quality parameters (Saraswati et al., 2014) and more sensitive and representative (Jubaedah et al., 2015). The determination of the quality status of the water with STORET index is through the comparison between the measurement data of water quality and the water quality standard that are tailored to its purpose. If the measurement result of the water quality meets the quality standard value that has been set (measurement result $\leq$ quality standard) then the score given is 0 ; If the measurement result of water quality does not meet the water quality standard value (measurement result $>$ quality standard), the score given is shown in Table 2.

Table 2. The determination of the score system

\begin{tabular}{cllc}
\hline \multirow{2}{*}{ Number of examples* $)$} & Score & \multicolumn{2}{c}{ Parameters } \\
\hline \multirow{2}{*}{10} & Maximum & -1 & Chemical \\
& Minimum & -1 & -2 \\
& Average & -3 & -2 \\
& Maximum & -2 & -6 \\
\hline 10 & Minimum & -2 & -4 \\
& Average & -6 & -4 \\
& & -12 \\
\hline
\end{tabular}

*) Number of parameters used in determining water quality status

The status of the river water quality was determined based on the number of scores obtained from the calculation of the number of the negative scores of all parameters and was compared with Table 3.

Table 3. The Determination of the water quality status based on STORET Index

\begin{tabular}{lll}
\hline No. & \multicolumn{1}{c}{ Score } & \multicolumn{1}{c}{ Criteria } \\
\hline 1. & 0 & Very good ( standard) \\
2. & $-1 \mathrm{~s} / \mathrm{d}-10$ & Good (lightly polluted) \\
3. & $-11 \mathrm{~s} / \mathrm{d}-30$ & Medium (moderately polluted) \\
4. & $\geq-31$ & Bad (heavily polluted) \\
\hline
\end{tabular}




\section{Results and Discussion}

\section{Temperature and $\mathrm{pH}$}

The water temperature of the Siak River at the high and the low tides was 28.96 to $31.16{ }^{\circ} \mathrm{C}$ and 29.36 to $30.81^{\circ} \mathrm{C}$ respectively. The lowest temperature at the high and low tides was found at the station 8 (Palas). Meanwhile, the highest temperature at the high and low tides was at the station 5. It shows that the temperature at the station 5 was higher than other stations (Table 4). In addition, the highest temperature at the station 5 was caused by the pulp and the paper mill, and at the time the pulp and paper waste was discharged into the Siak River. Based on the quality standard set out in GR No.82 / 2001 (class III), as the allowed values for temperature deviation of $30^{\circ} \mathrm{C}$, the water temperature of the Siak River at the whole stations still conformed the quality standard.
Furthermore, the $\mathrm{pH}$ value of the Siak water at the high tides was 5.0 to 7.5 and 4.8 to 6.7 at the low tides. Almost all stations had a pH $<6$ except at Station 1 (Siak Estuary) and the station 5 . At the high tide, the highest $\mathrm{pH}$ value was found at the station 1 (Siak Estuary), then the $\mathrm{pH}$ value decreased to the upstream except at the station 5 . The $\mathrm{pH}$ value at the low tide tended more acid because of $\mathrm{pH}$ of organic acid which was produced by the organic material decomposition coming from around the turf swamp. Leaching from litter and peat soil was the major source of dissolved organic matter in the Siak River (Rixen et al., 2010). The pH value of the Siak water was categorized as the lowest value that it is a black water River. In line with the statement of Alkhatib et al., (2007) stated that the black water river had the low $\mathrm{pH}$.

Table 4. The Water quality of downstream Siak River in Riau Province on tidal condition

\begin{tabular}{|c|c|c|c|c|c|c|c|c|c|c|c|}
\hline \multirow{2}{*}{ Parameter } & \multirow{2}{*}{ Unit } & \multirow{2}{*}{$\begin{array}{l}\text { Quality } \\
\text { standard }\end{array}$} & \multirow{2}{*}{$\begin{array}{c}\text { River } \\
\text { condition }\end{array}$} & \multicolumn{8}{|c|}{ Station } \\
\hline & & & & 1 & 2 & 3 & 4 & 5 & 6 & 7 & 8 \\
\hline \multirow[t]{2}{*}{ Temperature } & \multirow{2}{*}{${ }^{0} \mathrm{C}$} & Deviatio & High tide & 30.22 & 31.04 & 30.47 & 29.89 & 31.16 & 30.13 & 30.83 & 28.96 \\
\hline & & n 3 & Low tide & 30.42 & 30.33 & 29.41 & 30.13 & 30.81 & 29.89 & 30.43 & 29.36 \\
\hline \multirow[t]{2}{*}{$\mathrm{pH}$} & \multirow[t]{2}{*}{-} & \multirow[t]{2}{*}{$6-9$} & High tide & 7.5 & $5.7^{\star}$ & $5.2^{*}$ & $5.1^{*}$ & $5.9^{*}$ & $5.3^{*}$ & $5.2^{*}$ & $5.0^{*}$ \\
\hline & & & Low tide & 6.7 & $5.1^{*}$ & $5.1^{*}$ & $4.9^{*}$ & 6.7 & $5.2^{*}$ & $4.9^{*}$ & $4.8^{*}$ \\
\hline \multirow[t]{2}{*}{ TSS } & \multirow{2}{*}{$\mathrm{mg} / \mathrm{L}$} & \multirow[t]{2}{*}{400} & High tide & 74 & 48 & 60 & 12 & 20 & 22 & 17 & 18 \\
\hline & & & Low tide & 31 & 22 & 20 & 9 & 18 & 21 & 13 & 15 \\
\hline \multirow[t]{2}{*}{ Salinity } & \multirow[t]{2}{*}{$\%$} & \multirow[t]{2}{*}{-} & High tide & 25 & 1.5 & 0.0 & 0.0 & 0.0 & 0.0 & 0.0 & 0.0 \\
\hline & & & Low tide & 2.3 & 0.1 & 0.0 & 0.0 & 0.0 & 0.0 & 0.0 & 0.0 \\
\hline \multirow[t]{2}{*}{ DO } & \multirow{2}{*}{$\mathrm{mg} / \mathrm{L}$} & \multirow[t]{2}{*}{3} & High tide & 4.5 & 3.0 & $2.6^{*}$ & $1.8^{*}$ & $2.1^{*}$ & $2.6^{*}$ & $2.5^{\star}$ & 3.8 \\
\hline & & & Low tide & 3.0 & $2.8^{*}$ & $1.8^{*}$ & $1.3^{*}$ & $1.2^{*}$ & $2.9^{*}$ & $2.0^{\star}$ & 3.2 \\
\hline \multirow[t]{2}{*}{ BOD } & \multirow{2}{*}{$\mathrm{mg} / \mathrm{L}$} & \multirow[t]{2}{*}{6} & High tide & $29^{*}$ & $20^{*}$ & $20.3^{*}$ & $32^{*}$ & $39.2^{*}$ & $18.5^{*}$ & $18.6^{*}$ & $14^{*}$ \\
\hline & & & Low tide & $19^{*}$ & $17^{\star}$ & $24.9^{*}$ & $41.37^{*}$ & $45.6^{\star}$ & $20.2^{*}$ & $33.5^{\star}$ & $23.4^{*}$ \\
\hline \multirow[t]{2}{*}{ COD } & \multirow[b]{2}{*}{$\mathrm{mg} / \mathrm{L}$} & \multirow[t]{2}{*}{50} & High tide & $\underset{*}{51.76}$ & $61.95^{\star}$ & $56.43^{*}$ & $71.28^{*}$ & $80.62^{*}$ & $61.1^{*}$ & $62.8^{*}$ & $65.34^{*}$ \\
\hline & & & Low tide & $\underset{*}{51.76}$ & $67.47^{*}$ & $66.19^{*}$ & $56.01^{*}$ & $63.65^{\star}$ & $69.16^{*}$ & $64.5^{\star}$ & $52.61^{*}$ \\
\hline \multirow{2}{*}{$\mathrm{NO}_{3}-\mathrm{N}$} & \multirow{2}{*}{$\mathrm{mg} / \mathrm{L}$} & 20 & High tide & 0.28 & 0.13 & 0.19 & 0.21 & 0.16 & 0.15 & 0.16 & 0.15 \\
\hline & & & Low tide & 0.21 & 0.18 & 0.21 & 0.21 & 0.20 & 0.16 & 0.15 & 0.20 \\
\hline $\mathrm{NO}_{2}-\mathrm{N}$ & & 0.06 & High tide & $0.13^{*}$ & $0.14^{\star}$ & $0.14^{*}$ & $0.16^{*}$ & $0.17^{*}$ & $0.15^{\star}$ & $0.15^{\star}$ & $0.17^{\star}$ \\
\hline & $\mathrm{mg} / \mathrm{L}$ & & Low tide & $0.14^{*}$ & $0.13^{*}$ & $0.22^{*}$ & $0.15^{*}$ & $0.15^{*}$ & $0.14^{*}$ & $0.16^{*}$ & $0.15^{\star}$ \\
\hline $\mathrm{NH}_{3}-\mathrm{N}$ & & 0.02 & High tide & $1.09^{*}$ & $0.12^{*}$ & $0.08^{*}$ & $0.08^{*}$ & $0.09^{*}$ & $0.06^{*}$ & $0.04^{*}$ & $0.03^{*}$ \\
\hline & $\mathrm{mg} / \mathrm{L}$ & & Low tide & $0.92^{*}$ & $0.08^{*}$ & $0.09^{*}$ & $0.07^{*}$ & $0.1^{*}$ & $0.05^{*}$ & $0.03^{*}$ & $0.04^{*}$ \\
\hline Total & & 1 & High tide & 0.25 & 0.35 & 0.29 & 0.23 & 0.45 & 0.5 & 0.52 & 0.47 \\
\hline Phosphate & $\mathrm{mg} / \mathrm{L}$ & & Low tide & 0.31 & 0.49 & 0.51 & 0.68 & 0.71 & 0.35 & 0.6 & 0.44 \\
\hline Oil and Fat & $\mathrm{mg} / \mathrm{L}$ & 1000 & $\begin{array}{l}\text { High tide } \\
\text { Low tide }\end{array}$ & $\begin{array}{c}270 \\
233.3\end{array}$ & $\begin{array}{c}276 \\
252.0\end{array}$ & $\begin{array}{c}270 \\
213.6\end{array}$ & $\begin{array}{l}233.2 \\
233.2\end{array}$ & $\begin{array}{c}242.3 \\
312\end{array}$ & $\begin{array}{l}258.1 \\
263.2\end{array}$ & $\begin{array}{c}237.2 \\
534\end{array}$ & $\begin{array}{l}260.8 \\
264.6\end{array}$ \\
\hline Total & MPN/ & 10000 & High tide & $<300$ & $<300$ & $<300$ & $<300$ & $<300$ & $<300$ & $<300$ & $<300$ \\
\hline Coliform & 100 & & Low tide & $<300$ & $<300$ & $<300$ & $<300$ & $<300$ & $<300$ & 360 & $<300$ \\
\hline $\mathrm{Pb}$ & & 0.03 & High tide & 0.21 & 0.08 & 0.07 & 0.07 & 0.08 & 0.08 & 0.07 & 0.09 \\
\hline & $\mathrm{mg} / \mathrm{L}$ & & Low tide & 0.17 & 0.06 & 0.09 & 0.09 & 0.10 & 0.08 & 0.07 & 0.06 \\
\hline $\mathrm{Cd}$ & & 0.01 & High tide & 0.056 & 0.031 & 0.004 & 0.007 & 0.006 & 0.006 & 0.003 & 0.003 \\
\hline & $\mathrm{mg} / \mathrm{L}$ & & Low tide & 0.045 & 0.018 & $<0.002$ & $<0.002$ & 0.003 & $<0.002$ & 0.003 & $<0.002$ \\
\hline $\mathrm{Hg}$ & & 0.001 & High tide & $<0.01$ & $<0.01^{-2}$ & $<0.01^{-2}$ & $<0.01^{-2}$ & $<0.01^{-2}$ & $<0.01^{-2}$ & $<0.01^{-2}$ & $<0.01^{-2}$ \\
\hline & $\mathrm{mg} / \mathrm{L}$ & & Low tide & $<0.01$ & $<0.01^{-2}$ & $<0.01^{-2}$ & $<0.01^{-2}$ & $<0.01^{-2}$ & $<0.01^{-2}$ & $<0.01^{-2}$ & $<0.01^{-2}$ \\
\hline
\end{tabular}


Information*: not meeting class III quality standards (GR No. 82/ 2001)

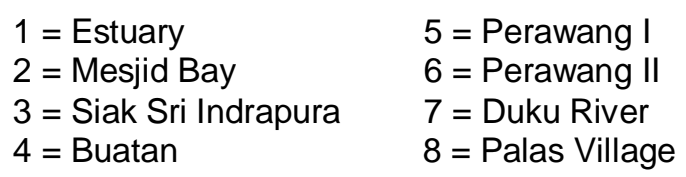

\section{TSS and salinity}

The Siak River has value the various total suspended solid. The total suspended solids on the successive high tide and low tide were 12 to $74 \mathrm{mg} / \mathrm{L}$ and $9-31 \mathrm{mg} / \mathrm{L}$. The highest value of suspended solids were either in the station 1 (high tide and low tide). The TSS value was high at the station 1 (the estuary of the river). It happened because there are tributaries around the estuary of the Siak; the small Siak Rivers which stream the suspended particle materials from around the turf swamps (Siegel et al., 2009). The values of the suspended solids in the Siak River water were generally still below the quality standard, <400 mg/L. Baum et al., (2007) reported that the Siak River had a low level of the total suspended matter.

The salinity values of the Siak River water at the high tide and the low tide respectively was 0 to $25 \%$ and 0 to $2.3 \%$. The highest salinity was found at the Station 1 (Siak Estuary) in both the high tides and the low tides. The salinity at the station 1 was higher than other stations because it was located at the mouth of the river and was influenced by a greater mass of sea water. At the low tides, the salinity values were lower due to the increasing mass of fresh water so that the level of salt in the water decreased. In general, the salinity between the high and low tide varies. The value tends to decrease to the upstream and the effect is not visible from the station 3 to the upstream. This is caused by turbulence water mass is strong enough so that the mass of water mixed homogenous (Siegel et al., 2009).

\section{Dissolved Oxygen (DO), BOD and COD}

The value of dissolved oxygen in the Siak water at the high tide and the low tide in a row was 1.8 to $4.5 \mathrm{mg} / \mathrm{L}$, the value of 1.2 to $3 \mathrm{mg} / \mathrm{L}$. The value of oxygen at the low tide was lower than at the high tide. At the low tide there was no influence of the mass of sea water. The characteristics of the Siak River contains the high dissolved organic carbon, it was subsequently decayed by microbial thereof reduced the concentration of oxygen in the water (Baum et al.,
2007; Rixen et al., 2008). Based on Table 4, the value of oxygen in the Siak water was considered low (Rixen et al., 2008; Rixen et al., 2010; Husna et al., 2014). King et al., (2012) explained that the River that had the characteristics of the Black River water contained low oxygen. The oxygen level was not in accordance with the quality standard $(<3 \mathrm{mg} / \mathrm{L})$, except at the station 1 (estuary) at the high tide and the low tide at the station 8 . The lowest oxygen value was found in the station 5, because the wasting activities of pulp and paper containing organic material was found in this station (Hossain and Ismail, 2015). The oxygen is low in the water caused by microorganisms which need oxygen to decompose organic matter (Kaur and Dua, 2016).

Biochemical Oxygen Demand (BOD) is a measure of oxygen that would be needed by the microorganism to decompose the organic and inorganic pollutants in polluted water (Uday and Anil, 2016). Pokhrel and Viraraghavan (2004); Tewari et al., (2009); Kamali and Khodapharast (2015) also reported that BOD was one of the main pollutants resulted from the production of pulp and paper in the pulping and bleaching stages. The BOD values in the water of the Siak River were from 14 to $39.2 \mathrm{mg} / \mathrm{L}$ at the high tide and $17-45.6 \mathrm{mg} / \mathrm{L}$ at the low tide. It was generally considered that the $\mathrm{BOD}$ value at the whole stations already far exceeded the quality standard $(<6 \mathrm{mg} / \mathrm{L})$ at the high tides and the low tides. BOD values in the Siak River water at low tides tended to be higher than at the high tides. The highest $B O D$ value was found in the station 5 , which happened at the high and the low tide. The high BOD levels indicated a decline in DO because the oxygen that was available in the water was being consumed by the bacteria leading to the inability of fish and other aquatic organisms to survive in the river (Waziri and Ogugbuaja, 2010).

The COD value in the water of the Siak River in the high tide was from 51.76 to 80.62 $\mathrm{mg} / \mathrm{L}$, whereas at the low tide was 51.76 to 69.16 $\mathrm{mg} / \mathrm{L}$. The results showed that the COD value varied during the high tides and the low tides. The COD value in the Siak River water in the whole observation stations passed the quality standard of $<50 \mathrm{mg} / \mathrm{L}$ (GR No.82 / 2001 grade 
III), both at the high tide and low tide. This was a presumption because along the Siak River, there were many industries that dumped waste into the Siak water (Baum and Rixen, 2014). The highest COD value was found at the station since the station had pulp and paper waste. Hossain and Ismail (2015) stated that the pulp and paper waste contained the high levels of COD. The decreasing oxygen levels and the increasing values of $B O D$ and $C O D$ in water indicated that the water contained the high levels of dissolved organic components (Uday and Anil, 2016).

\section{Ammonia, nitrate, nitrite and total phosphate}

The level of ammonia in the Siak varied, it was about $0.03-1.09 \mathrm{mg} / \mathrm{L}$ at the high tide and $0.03-0.92 \mathrm{mg} / \mathrm{L}$ at the low tide (Tabel 4). The station 1 in the mouth of the river of both the high tide and the low tide recorded the highest values were $1.09 \mathrm{mg} / \mathrm{L}$ and $0.92 \mathrm{mg} / \mathrm{L}$, respectively. Based on the analysis of the ammonia levels at the whole stations at the high tide and the low tide, it exceeded the standard quality boundary (0.02 mg/L) (GR No.82 / 2001 grade III). Around the Siak, there are palm plantations. Baum and Rixen (2014) reported that the fishing areas of the river were really influenced by the area conversion becoming palm plantations. In Riau Province, the width of industrial areas of palm plantations consists of approximately $16.000 \mathrm{~km} 2$ or $19.97 \%$ of the width of total areas of Riau Province (Baum and Rixen, 2014). The residue of fertilizer which streamed when it was raining flowed into the Siak; as a result, it can improve the level of ammonia in the river. The higher ammonia value can be toxic for fish, but in small concentrations, it can serve as nutrients for excessive growth of algae (Corwin et al., 1999).

In general, the nitrate concentration at the high and the low tide was not extremely different. At the high tide, the nitrate concentration was $0.13-0.28 \mathrm{mg} / \mathrm{L}$ and at the low tide was 0.15 $0.21 \mathrm{mg} / \mathrm{l}$, and the highest level of nitrate was $(0.28 \mathrm{mg} / \mathrm{L})$ at the station 5 (at the high tide). While the lowest level of nitrate was found at the low tide $(0.13 \mathrm{mg} / \mathrm{L})$ at the station 2 . Generally, the concentration level of nitrate was still below the standard quality (20 mg/L) (GR No.82 / 2001 grade III). A study revealed that nitrate content was lower, which might be due to its utilization by phytoplankton and macrophytes (Singh et al., 2016). Nitrate pollution in the river basin might be mainly sourced from the use of chemical fertilizer and pesticide in the agricultural area, domestic sewage, and industrial waste water discharge (Ying et al., 2016).

Concentrations of nitrites for the whole station of the Siak River were relatively stable in the high tide and in the low tide (table 4), except in station 3 (the high tide). The nitrite concentration in present study ranged 0.13 to $0.17 \mathrm{mg} / \mathrm{L}$ (the high tide) and 0.13 to $0.22 \mathrm{mg} / \mathrm{L}$ (the low tide). The nitrite content which is allowed in rivers is not more than $0.06 \mathrm{mg} / \mathrm{L}$, therefore, the value of nitrite content in this research at the whole observation stations exceeded the standard quality. Around the Siak, starting from Pekabaru city to Perawang and Siak Sri Indrapura, there are rubber industries, paper processing and palm plantations. The exposure and treatment of industrial sewage from rubber and paper processing industries are heavily enriched in nitrogen components (Agamuthu, 1999). Baum and Rixen, (2014) reported that the waste of rubber industries, paper processing and palm plantations improved the nitrogen component in the Siak river.

In the present study, phosphate value ranged 0.23 to $0.52 \mathrm{mg} / \mathrm{L}$ at the high tide and 0.31 to $0.71 \mathrm{mg} / \mathrm{L}$ at the low tide. Generally, the total content of phosphate is higher at the low tide than the high tide. The total content of phosphate in the Siak was still below the standard quality; 1 mg/L (GR No.82 / 2001 grade III). The higher values of phosphate were recorded at the station 5, which might be due to the anthropogenic activities. Baum and Rixen (2014) thought that the domestic waste would improve the phosphate content in the Siak about $470 \%$. The highly relative content of phosphate at this station was thought that it came from the wasting activities of pulp and paper. According to Cousins et al., (2014), the pulp and the paper waste contained phosphate which was high enough. The high phosphate content was caused by organic material decomposition which was leached from the turf swamp. According to Baum and Rixen (2014), one of the factors which controlled the phosphate content in the Siak was the leaching of organic material which came from the turf swamp.

\section{Total coliform, oil and fat}

Overall total coliform levels in the study area was still below the standard quality $(<10000$ $\mathrm{ml}$ ) and there was no difference except at the station 7 (the low tide), which is higher (360 MPN/100). At the low tides, the sewage of the settlements was thrown into the water surface of 
the Siak through the small channels. The station 7 was a dense residential area (Pekanbaru). The number of population in Pekanbaru city was one million people (CSA Riau Province, 2016). Liebezeit and Wostmann (2010) stated that the most dominant fecal contamination in the water of the Siak River in Pekanbaru was caused by the large population. Mallin et al., (2000) explained that the abundance of fecal coliform significantly correlated with the number of inhabitants in the basin, and even highly correlated with the percentage of land area developed in the watershed.

The values of oil and fat in the water of the Siak River in a row were 233.2-270 mg/L (the high tide) and 213.6-534 $\mathrm{mg} / \mathrm{L}$ (the low tide). Based on the water quality standard, the amount of oil and grease in the area of research was still far below the standard of quality $<1000 \mathrm{mg} / \mathrm{L}$ levels of oil and grease which was the highest at the station 7 (low tide). This was because the station 7 was a densely populated residential area. At the low tides, the domestic sewage of the settlements was thrown into the water surface through the Siak River drainage and rivers.

\section{$\mathrm{Pb}, \mathrm{Cd}$ and $\mathrm{Hg}$ metal}

In this study, $\mathrm{Pb}$ concentration in the Siak River ranged 0.07 to $0.21 \mathrm{mg} / \mathrm{L}$ at the high tide, and 0.06 to $0.17 \mathrm{mg} / \mathrm{L}$ at the low tide. The highest concentration of $\mathrm{Pb}$ was recorded in the station 1 (the mouth of the river) both of tides. $\mathrm{Pb}$ concentration in the whole observation stations in both the high tides and low tides passed quality standard which was $0.03 \mathrm{mg} / \mathrm{L}$ (GR No. 82/2001). The Higher concentration of $\mathrm{Pb}$ was observed at the mouth of the river area (the station 1) compared with other stations. The sources of $\mathrm{Pb}$ came from industrial activities and the settlements. Arifin (2001) reported that $\mathrm{Pb}$ concentration was correlated to the population density in each province in Indonesia.

The concentration of $\mathrm{Cd}$ varied from 0.003 to $0.007 \mathrm{mg} / \mathrm{L}$, at the high tide, and from $<0.002$ to $0.045 \mathrm{mg} / \mathrm{L}$ at the low tide. Cd concentration tended to be higher at the high tide. At the high tide, the Cd level in all observation stations generally was still below the quality standard except at the stations 1 and 2 . The highest level of the metal cadmium was found in the station 1 , which was the Siak estuary. At the low tide, the overall level of the metal cadmium in all stations was $<0.002$, except at the stations 1 and 2 , which passed the quality standard (GR No. 82/2001 Class III). It showed that the $\mathrm{Cd}$ level found was higher in the Siak which was still influenced by salinity. Hg concentration in the Siak water at the whole stations in both the high tide and the low tide was $<0.0001 \mathrm{mg} / \mathrm{L}$ level which was still far below the standard of quality; only $0.001 \mathrm{mg} / \mathrm{L}$ (GR No. 82/2001 Class III). It was assumed that only a few sources of heavy metal $\mathrm{Hg}$ contributed to the Siak water. The possible contamination of $\mathrm{Hg}$ might come from point sources and non-point sources of pollutants.

Evaluation on the quality of the Siak water by using STORET index on tidal conditions

Evaluation on the quality of the Siak water by using the STORET index when tides came is shown in Table 5. Based on the index STORET, the water quality of the Siak on tidal conditions was categorized as heavy polluted at the whole observation stations; the values were -52 to -70 . At the high tide, the STORET index kept increasing from at the station 1 (the Siak estuary) to the station 3 . This is caused by pollutants from seawater carried out along with high tide in station 3. Furthermore, the STORET index tended to decrease to the upstream. While at the low tide, the index STORET tended to increase from the upstream to the downstream and reach the peak in the station 2 . It is indicated because of pollutants which from activity alongside of the river that brought at high tide then it is more increase in downstream that is in station 2. The value of STORET index at the high tide generally was higher than at the low tide. It showed that the influence of the mass of sea water (at the high tide) which streamed into the Siak could cause the pollution level of the Siak increasing. 
Table 5. The scores of STORET index of the Siak River water on tidal conditions

\begin{tabular}{|c|c|c|c|c|}
\hline \multirow[t]{2}{*}{ The Stations } & \multicolumn{4}{|c|}{ Indeks Storet } \\
\hline & $\begin{array}{c}\text { The High Tide } \\
\text { Scores }\end{array}$ & Characteristics & $\begin{array}{c}\text { The Low Tide } \\
\text { Scores }\end{array}$ & Characteristics \\
\hline 1 & -58 & & -52 & \\
\hline 2 & -60 & $\frac{T}{D}$ & 70 & $\underset{\mathbb{D}}{\mathrm{T}}$ \\
\hline 3 & -70 & $\stackrel{\text { D }}{<}$ & -68 & $\stackrel{0}{2}$ \\
\hline 4 & -68 & ऐ & -64 & $\gtreqless$ \\
\hline 5 & -68 & ర & -64 & 0 \\
\hline 6 & -66 & $\overline{\bar{c}}$ & -64 & $\overline{\bar{E}}$ \\
\hline 7 & -66 & $\stackrel{\mathbb{\Phi}}{\varrho}$ & -60 & $\stackrel{\overparen{\mathbb{D}}}{\varrho}$ \\
\hline 8 & -52 & & -58 & \\
\hline
\end{tabular}

The scores of the STORET index in this research was lower than the result of the research done by EA (2013) (-94 to -174) and MOEAF (2015) (-52 to -89). The different from this research, the index STORET that was obtained by EA (2013) and MOEAF (2015) in the Siak River was not based on tidal conditions. Based on the result of the index STORET scores, it can be concluded that the Siak River starting from the Siak Estuary to upstream did not meet on the water quality of the class III at both the high tide and the low tide.

\section{Conclusion}

The quality of water in the Siak River varies greatly based on tidal condition. It shows that pollution in downstream in the Siak River influenced by the tide. The quality of water in the Siak downstream at the high tide and the low tide does not meet the standard quality of the class III Government Rule No.82/200; for the parameters of $\mathrm{DO}, \mathrm{BOD}, \mathrm{COD}$, ammonia, nitrite and $\mathrm{Pb}$ metal. Based on the index STORET, the Siak River was categorized as heavily polluted at the high and low tide. At the high tide, the scores of the index STORET keep increasing to the upstream, in the contrary, at the low tide, the scores of the index STORET keep increasing to the downstream

\section{References}

Agamuthu, P. 1999. Specific biogas production and role of packing medium in the treatment of rubber thread manufacturing industry wastewater. Bioprocess Engineering 21. 151-155.
Ahmed, F., Aziz, M.A., Alam, M.J., Hakim, M.A., Khan, M.A.S., Rahman, M.A. 2015. Impact on aquatic environment for water pollution in the Vahirab River. The International Journal of Engineering and Science 4. 56-62.

Alkhatib, M., Jennerjahn T.C., Samiaji, J. 2007. Biogeochemistry of the Dumai River estuary, Sumatra, Indonesia, a tropical blackwater river. Limnology and Oceanography 52. 2410-2417.

Amri, H.T.A. 2007. Pollution control in conservation efforts Watershed (DAS) Siak. Journal of Sains MIPA 13. 153-162.

[APHA] American Public Health Association. 2012. Standard methods for the examination of water and waste water. $21^{\text {st }}$ ed American Public Health Association (APHA). USA Port City Press. Washington DC.

Arifin, Z. 2001. Heavy metal pollution in sediments of coastal waters of Indonesia.https://www.researchgate.net/pu blication/228406669_Heavy_Metal_Polluti on_in_Sediments_of_Coastal_Waters_of_I ndonesia

Azizullah, A., Khattak, M.N.K., Richter, P., Hader, D.P. 2011. Water pollution in Pakistan and its impact on public health. Review. Enviromental International 37. 479-497.

Baum, A., Rixen, T. 2014. Dissolved inorganic nitrogen and phosphate in the human affected blackwater River Siak. Central Sumatera Indonesia. Asian Journal of Water Environmental and Pollution 11. 1314.

Baum, A., Rixen, T., Samiaji, J. 2007. Relevance of peat draining rivers in central Sumatra 
for the riverine input of dissolved organic carbon into the ocean. Estuarine, Coastal and Shelf Science 73. 563-70.

Bhuiyan, A.B., Mokhtar, M.B., Toriman, M. E., Gasim, M.B., Goh, C.T., Elfithri, L., Razman, M.R. 2013. The environmental risk and water pollution: A review from the river basins around the world. AmericanEurasian Journal of Sustainable Agriculture 7. 126-136.

Chihhao, F., Chun, H.K., Wei, S.W. 2009. An Innovative modeling approach using Qual2K and HEC-RAS integration to assess the impact of tidal effect on river water quality simulation. Journal of Environmental Management 90. 18241832.

Corwin, D.L., Loague, K.., Ellsworth, T. R. 1999. Advanced information technologies for assessing nonpoint source pollution in the Vadose Zone: conference overview," Journal of Environmental Quality 28. 357365.

Cousins, M., Koons, M., Macek, A., Sherwood, L., Starovasnik, C. 2014. Water quality analysis of effluent discharge effects on the Sampit River from international paper mill in Georgetown South Carolina.

[CSA] Central Statistics Agency. 2016. Central Statistics Agency of Riau Province. Riau Province in numbers.

[DCCOES] Development Control Center of Ecoregion Sumatera. 2015. Ministry of Environmental and Forestry. Calculation of load pollution capacity of Siak River.

[DOPW] Department of Public Works. 2005. Spatial planning Siak Watershed (DAS) Riau Province. Exposure of the minister of public works at the seminar rescue and preservation of watersheds Siak. Pekanbaru 6 Agustus 2005

Dimitrovska, O., Markoski, B., Toshevska, B.A., Milevski, I., Gorin, S. 2012. Surface water pollution of major rivers in the Republic of Macedonia. Procedia Environmental Sciences.14. 32-40.

[EA] Environment Agency. 2015. Minimum service standards report environment agency of Riau Province.

Gasim, M.B., Khalid, N.A., Muhammad, H. 2015. The Influence of tidal activities on water quality of Paka River Terengganu, Malaysia. Malaysian Journal of Analytical Sciences19. 979-990.

[GR] Government Regulation. 2001. Government Regulation of Indonesia No 82 /2001 on Water Quality And Water Pollution Management.

Hossain, K., Ismail, N. 2015. Bioremediation and detoxification of pulp and paper mill effluent: A Review. Research Journal of Environmental Toxicology 9. 113-134.

Husnah, Grote, B., Kaban, S. 2014. Lead and cadmiun concentrations in the Catfish Pangasius Polyuranodon (Bleeker 1852) from the Siak River, Riau Province, Indonesia. Asian Journal of Water, Environment and Pollution 11. 41-49

Iskandar, Dahiyat. 2012. The diversity of fish in the River Siak Riau. Journal of Biological Sciences and Physical. 14. 51-58.

Ismy, F., Ashar, T., Dharma, S. 2012. Analysis of water quality and skin disorders in the user community in the Siak River water River port Duku Village Tanjung Rhu District of Limapuluh Kota Pekanbaru. Jurnal.usu.ac.id/index.php/lkk/article/downl oad/1561/816. Downloaded in 25 April 2015.

Jubaedah, D., Hariyadi, S., Muchsin, I., Kamal, M.M. 2015. Water quality index of floodplain River Lubuk Lampam South Sumatera Indonesia. International Journal of Environmental Science and Development 6. 252-258.

Kamali, M., Khodaparast, Z. 2015. Review on recent developments on pulp and paper mill wastewater treatment. Ecotoxicology Environmental Safety 114. 326-342.

Kaur, R., Dua, A. 2016. Assessment of water quality of Tung Drab Drain an international water channel using multivariate statistical techniques. Asian Journal of Water Environmental and Pollution 13.85-93.

King, A. J., Tonkin, Z., Lieshcke, J. 2012. Shortterm effects of a prolonged black water event on aquatic fauna in the Murray River, Australia: considerations for future events. Marine and Freshwater Research 63. 576-586.

Lee, A.H., Nikraz,H. 2015. BOD: COD ratio as an indicator for River pollution international 
Proceedings of Chemical, Biological and Environmental Engineering 88. 89-94.

Liebezeit, G., Wostmann, R. 2010. Corpostanol in Siak River sedimen, E Sumatra, Indonesia. Bulletin Environmental Contamination Toxicology 85. 585-588.

Mallin, M.A., William K.E., Esham, E.C., Lowe, E.P. 2000. Effect of human development on bacteriological water quality in coastal watersheds. Ecological Agrlications 10. 1047-1056.

[MOE] Ministry of Environment. 2003. Ministry of environment decree No 115/2003 on guidelines for determination of water quality status.

[MOE] Ministry of Environment. 2013. Report on the implementation of water quality monitoring 33 provinces. Central means of controlling environmental impacts. Deputy development technical support and capacity building. Jakarta.

[MOEAF] Ministry of Environmental and Forestry. 2015. Atlas water quality status Indonesia 2015.

Nedi, S. 1999. Water quality assessment Siak River in Pekanbaru municipality and Siak District of Bengkalis. Journal of Natur Indonesia.

Nurhamidah, Junaidi, A., Anggraini, L. 2016. An immediate review of flood characteristics on delta lowland Sumatra using D8 model spatial analysis. International Journal of Earth Sciences and Engineering 9. 436 442.

Pokhrel, D., Viraraghavan, T. 2004. Treatment of pulp and paper mill wastewater $A$ review. Science of the Total Environment 333. 3758.

Putri, M. R., Pohlmann, T. 2014. Lagrangian model simulation of passive tracer dispersion in the Siak Estuary and Malacca Strait. Asian Journal of Water, Environment and Pollution 11. 67-74.

Ratnaningsih, D. 2010. Implementation of STORET method for water quality parameters in Indonesia Rivers. Ecolab 4. $1-54$.

[RBA III Sumatera] River Basin Agency III Sumatera.2015. Watersheds management pattern of River Siak.
Rim-Rukeh, A. 2016. Assessment of water quality in a tidal river system using river pollution index (RPI). Journal of Environmental Science and Pollution 2. 72-75.

Rixen, T., Baum, A., Polhmann, T. 2008. The Siak, a tropical black water river in central Sumatra on the verge of anoxia. Biogeochemistry 90.129-140.

Rixen, T., Baum, A., Sepryani, H., Polhmann, T., Jose, C., Samiaji, J. 2010. Dissolved oxygen and its response to eutrophication in a tropical black water River. Journal of Environmental Management 91. 17301737.

Saraswati, S.P., Sunyoto, Bambang Agus Kironoto, B.A., Hadisusanto, S. 2014. Assessment of the forms and sensitivity of the index formula PI, Storet, CCME for The Determination of water quality status of a tropical stream in Indonesia. Journal Human and Environment 21. 129-142

Sholichin, M., Othman, F., Limantara, L.M. 2010. Use of PI and Storet methods to evaluate water quality status of Brantas River. Journal of Mathemati cs and Technology 1, 116-124.

Siegel, H., Stottmeister, I., Reibmann J., Gerth, M., Jose, C., Samiaji, J. 2009. Siak River system East-Sumatra characterisation of sources, estuarine processes, and discharge into the Malacca Strait. Journal of Marine System 77.148-159.

Singh, M.K., Tripathi, A.K., Jeeva, V. 2016. Limnological study of Asan Wetland in relation to water quality in doon Valley, Uttarakhand, India. Asian Journal of Water, Environment and Pollution, 13. 1726.

Suthar, S., Nema, A.K., Chabudkdhara, M., Gupta, S.K. 2009. Assesment of metals in water and sediment of Hindon River, India: Impact of industrial and urband discharges. Journal of Hazardous Material 171. 1088-1095.

Tallar, R.Y., Jian-Ping, S. 2015. Identification of water body status in Indonesia by using predictive index assessment tool. International Soil and Water Conservation Research. 1-33. 
Tewari, P.K., Batra, V.S., Balakrishnan, M. 2009. Efficient water use in industries: cases from the Indian agro-based pulp and paper mills. Journal Environmental Management 90. $265-273$.

Toriman, O.E., Hasyim, N., Hassan, A.J., Mokhtar, M., Juahir, H., Gasim, M.B., Abdullah, M.P. 2011. Study on the impact of tidal effects on water quality modelling of Juru River, Malaysia. Asian Journal of Scientific Research 4. 129-138

Uday, B.P., Anil, K.D. 2016. Free oxygen budget of a polluted tropical river. Hydrology Current Research 7. 1-4.

Waziri, M., Ogugbuaja, V.O. 2010. Interrelationships physicochemical water pollution indicators: A case study of River Yobe-Nigeria. American Journal of Scientific and Industrial Research 1. 76-80.

Wit, F., Muler D., Baum A., Warneke, T., Pranowo, W.S., Muller, Rixen, T. 2015. The impact of disturbed peat lands on River outgassing in Southeast Asia. Nature Communications 6. 10155.

Ying, X., Song, J., Zhang, Y., Kong, F., Wen, M., Zhang, G. 2016. Nitrate pollution and preliminary source identification of surface water in a semi-arid river basin, using isotopic and hydro chemical Approaches. Water 8. 1-12. 